\title{
Economic values for a total merit index of dairy goats in Austria
}

\section{Wirtschaftliche Gewichte für einen Gesamtzuchtwert für Milchziegen in Österreich}

\author{
Birgit Fuerst-Waltl ${ }^{1}$, Birgit Lang ${ }^{1,2}$, Christian Fuerst ${ }^{3}$
}

\author{
${ }^{1}$ University of Natural Resources and Life Sciences Vienna (BOKU), Gregor Mendel-Straße 33, 1180 Vienna, Austria \\ 2 present address: Landwirt Agrarmedien GmbH, Hofgasse 5, $8010 \mathrm{Graz}$, Austria \\ ${ }^{3}$ ZuchtData EDV-Dienstleistungen GmbH, Dresdner Straße 89/19, 1200 Vienna, Austria \\ Corresponding author: birgit.fuerst-waltl@boku.ac.at
}

Received: 23 February 2018, received in revised form: 29 June 2018, accepted: 23 July 2018

\begin{abstract}
Summary
When defining a total merit index, all economically important traits, both performance and functional traits shall be considered. Aside from breeding values, their reliabilities and all genetic relationships, the knowledge of the economic importance of all traits involved is required. In this study, economic values were derived for the most numerous dairy goat breed in Austria, the Saanen goat. Calculated marginal utilities are expressed per average ewe place and year. The calculations were based on a herd model including dairy production, rearing and fattening of goat kids. Economic values are calculated by multiplying the marginal utilities with the genetic standard deviations of the traits. The economic value is thus defined by the value of one unit of genetic superiority of a trait. In order to derive the economic value of one trait, a single parameter in the model was varied while keeping all other traits constant. The relative economic values (in \%) for the trait complexes were as follows: dairy : functional : meat traits $=74: 25: 1$, respectively. Within the dairy complex, milk carrier yield was the most important trait, while in the functional traits fertility, defined as conception rate, had the highest economic weight.
\end{abstract}

Keywords: Dairy goats, economic value, total merit index, breeding program, breeding goal

\section{Zusammenfassung}

Wird im Rahmen eines Zuchtprogramms ein Gesamtzuchtwert definiert, sollen alle wirtschaftlich relevanten Merkmale, sowohl Leistungs- als auch funktionale Merkmale, berücksichtigt werden. Neben Zuchtwerten, deren Sicherheiten und genetischen Beziehungen zwischen den beteiligten Merkmalen oder Merkmalskomplexen, ist daher auch die Kenntnis der wirtschaftlichen Bedeutung relevant. Im Rahmen dieser Arbeit wurden wirtschaftliche Gewichte für die zahlenmäßig wichtigste Ziegenrasse in Österreich, die Saanenziege, abgeleitet. Die Berechnung der Gewichte erfolgte mittels eines Herdenmodells mit Milchproduktion, Aufzucht und Kitzmast. Das wirtschaftliche Gewicht eines Merkmals entspricht dem ökonomischen Wert der genetischen Leistungsverbesserung gegenüber dem Populationsdurchschnitt um eine genetische Standardabweichung je Herdendurchschnittstier und Jahr. Für die Ableitung des wirtschaftlichen Gewichts eines Merkmals wurde jeweils ein Parameter im Referenzszenario geringfügig variiert und der neu berechnete Gewinn mit jenem der Ausgangssituation verglichen. Die wirtschaftlichen Gewichte der Merkmalsgruppen Milch : Fitness : Fleisch verteilten sich auf $74 \%: 25 \%: 1 \%$. Innerhalb der Milchmerkmale hat die Milchmenge, innerhalb der funktionalen Merkmale die Fruchtbarkeit, definiert als Konzeptionsrate, das größte wirtschaftliche Gewicht.

Schlagworte: Milchziegen, wirtschaftliche Gewichte, Gesamtzuchtwert, Zuchtprogramm, Zuchtziel 


\section{Introduction}

In Austria, the number of dairy goats as well as the amount of goat milk produced has increased markedly during the last years. In the year 2016, approximately 21,600 t of goat milk was produced by about 33,000 dairy goats (Statistik Austria, 2017). In the same year, in total about 83,000 goats were kept in Austria, of which roughly 17,000 were breeding goats. The main breed is the Saanen goat, a dairy breed, with almost 10,000 breeding animals (ÖBSZ, 2017).

In order to ensure a long-term sustainable development and to remain competitive, goat breeding organizations have focused on the revision of the breeding objectives and the establishment of a routine genetic evaluation during the recent years. Next to performance testing, both are indispensable in modern breeding programs. To facilitate selection, breeding values of production and fitness related traits are ideally combined to a total merit index (TMI), which represents the mathematical definition of the breeding objective. Within the TMI, respective traits or trait groups need to be weighted according to their importance. The selection index theory (Hazel and Lush, 1942) is the basis for weighting optimally. Aside from breeding values, their reliabilities and all genetic relationships, the knowledge of the economic importance of all traits, that is, economic values, is thus necessary. Economic values represent the value of one unit superiority of a trait when all other traits in the aggregate genotype remain constant (Hazel, 1943). Given that the relative levels of economic values in the TMI are accurate, optimum levels of genetic improvement may be expected (Groen et al., 1997).

The aim of the current study, therefore, was to derive economic values for dairy, meat and functional traits for the Austrian dairy goats, represented by the Saanen goat.
These serve as a starting point for the establishment of a TMI that is economically feasible but also sustainable in the long-term.

\section{Model, Assumptions and Traits}

\subsection{Model}

The original version of the computer programme used aimed at the optimization of management-related decisions for cattle (Amer et al., 1996). To derive the economic values, various modifications were made (Miesenberger, 1997). Later, the program was adapted for sheep (FuerstWaltl and Baumung, 2009) and for the current study also for dairy goats. A dairy goat herd with milk production, rearing of replacement stock and kid fattening was modelled over an infinite planning term. All relevant costs and revenues from selling milk, fattened kids and replacement animals were calculated per day. According to Smith et al. (1986), all the costs (including fixed costs) were regarded as variable. Daily results were weighted by the proportion of goat classes and summarized over the kidding interval or until culling. Goat classes resulted from the assumed percentage of culls for infertility, involuntary (except for infertility), and voluntary reasons in each lactation (Table 1). The economic value of a trait was derived by calculating the difference in herd profit before (reference scenario) and after improvement by genetic change (alternative scenarios). Within each scenario, the herd distribution was maintained over time. Economic values were derived separately for each trait while keeping all other traits constant in order to avoid double counting (Dempfle, 1992). Results are expressed per average goat place and year. Follow-

Table 1. Age structure for Saanen goats shown as proportions (\%) of goat classes by lactation and fate (INV = involuntary culling except for infertility; FER = culling for infertility; VOL = voluntary culling; SUR = survivors; TOT = total) in the reference scenario Tabelle 1. Altersstruktur für Saanenziegen dargestellt als Anteile (\%) der Ziegenklassen nach Laktationsnummer und Schicksal (INV = unfreiwillige Merzung außer auf Grund von Fruchtbarkeitsproblemen; FER = Merzung auf Grund von Fruchtbarkeitsproblemen; $\mathrm{VOL}=$ freiwillige Merzung; SUR = Überlebende; TOT $=$ gesamt) im Referenzszenario

\begin{tabular}{lccccccccc}
\hline & \multicolumn{1}{c}{ Lactation } \\
\hline INV & 1 & 2 & 3 & 4 & 5 & 6 & 7 & $8+$ \\
FER & 2.12 & 2.39 & 2.81 & 2.40 & 3.20 & 2.35 & 1.36 & 1.06 \\
VOL & 0.81 & 0.66 & 0.54 & 0.41 & 0.78 & 0.58 & 0.47 & 0.20 \\
SUR & 1.85 & 1.09 & 0.88 & 0.53 & 0.00 & 0.00 & 0.00 & 0.00 & 0.00 \\
TOT & 21.71 & 17.58 & 13.35 & 10.00 & 6.02 & 3.09 & 1.26 & 3.09 & 1.75 \\
\hline
\end{tabular}


ing Miesenberger (1997) and Fuerst-Waltl and Baumung (2009), marginal utilities in $€$ per improvement of one unit of the respective traits, economic values in $€$ per genetic standard deviation as well as relative economic values for single traits and trait complexes were calculated.

\subsection{Assumptions}

In Table 1, the age structure for the reference scenario is illustrated. The proportions in different classes as well as further population parameters (Table 2) are based on breed specific data evaluations, annual reports, and information provided by experts from the federal breeding organizations. The Wood-function (Wood, 1967):

$y_{t}=a \times t^{b} \times e^{c t}$

with $y_{t}$ being milk, fat or protein performance on day $t$ and $\mathrm{a}, \mathrm{b}$, and $\mathrm{c}$ being constants that specify the shape of the lactation curve, was applied to estimate daily milk, fat and protein yield. The constants $\mathrm{b}$ and $\mathrm{c}(\mathrm{b}=$ rate of increase until lactation peak and $\mathrm{c}=$ rate of decline after the lactation peak) were defined for milk, fat and protein content (Table 3), while a (initial milk yield) was calculated by the given milk production potential in the first, second and higher lactations. Table 3 shows the assumed Wood- parameters for the reference scenario. Further details are provided by Fuerst-Waltl and Baumung (2009).

Daily gains and weights of fattened kids were based on the function of Gompertz (Fitzhugh, 1976):

$L M_{t}=a \times e^{-b e^{-k t}}$

with $\mathrm{LM}_{\mathrm{t}}$ being the live mass on day $\mathrm{t}$, a being the asymptote, while $\mathrm{b}$ and $\mathrm{k}$ denote slope and point of inflexion, respectively. For the reference scenario, the values $\mathrm{a}=54.9$, $\mathrm{b}=1.90$ and $\mathrm{k}=0.0086$ were assumed. The $\mathrm{a}$ and $\mathrm{b}$ values were adopted from Regadas Filho et al. (2013), the k-value was however changed from 0.0041 to 0.0086 to coincide better with the situation of the Austrian Saanen goat. $\mathrm{LM}_{\mathrm{t}}$ of a female animal is described by the function:

$L M_{t}=M M-(M M-B M) \times e^{-.006 t}$

with $\mathrm{MM}$ and $\mathrm{BM}$ denoting the live, mature $(\mathrm{MM}=$ $70 \mathrm{~kg}$ ) and birth mass, respectively. For breeding bucks, the exponential parameter was -0.004 with an assumed mature mass of $90 \mathrm{~kg}$. In total, $5 \%$ of male animals were assumed to be sold for breeding.

Costs and prices for labor, feedstuff, milk, carcasses, breeding animals, or inseminations (Tables 4 and 5) were based on a recent study on cattle (Fuerst-Waltl et al., 2016) as well as further market reports and information provided by ex-

Table 2. Selected population parameters for the Saanen goats in the reference scenario

Tabelle 2. Ausgewählte Populationsparameter für Saanenziegen im Referenzszenario

\begin{tabular}{lc}
\hline Trait (unit) & Value \\
\hline Standard lactation (d) & 240 \\
Age at first kidding (d) & 395 \\
$1^{\text {st }}$ lactation milk yield (standard lactation, kg) & 552 \\
Age factors milk yield in lactations $2 / 3 / 4 / 5 / 6+^{1}$ & $1.27 / 1.39 / 1.41 / 1.40 / 1.32$ \\
Fat content $1^{\text {st }}(\%)$ & 3.29 \\
Protein content $1^{\text {st }}(\%)$ & 3.04 \\
Proportion of single/twin/triple births (\%) & $50 / 43 / 7$ \\
Proportion easy/medium/difficult kidding (\%) & $85 / 10 / 5$ \\
Length of productive life (y) & 3.26 \\
Kidding interval (d) & 354 \\
Stillbirth rate (\%) & 5 \\
Rearing losses (\%) & 7 \\
Live weight, fattened male kids (kg) & 20 \\
Daily gain, fattened male kids (g) & 270 \\
Dressing percentage (\%) & 50 \\
Age of maiden goats sold (d) & 180 \\
Age of breeding rams sold (d) & 180 \\
Mature weight female goat (kg) & 70 \\
\hline
\end{tabular}

${ }^{1}$ Milk yield in higher lactations is calculated by multiplying the $1^{\text {st }}$ lactation milk yield $(552 \mathrm{~kg})$ with the respective age factor 
Table 3. Parameters of the Wood function (Wood, 1967) for dairy goats in first, second and higher (3+) lactations

Tabelle 3. Parameter der Wood-Funktion (Wood, 1967) für Milchziegen in der ersten, zweiten und höheren (3+) Laktationen

\begin{tabular}{ccccccc}
\hline & \multicolumn{2}{c}{ Carrier yield } & \multicolumn{2}{c}{ Fat percentage } & \multicolumn{2}{c}{ Protein percentage } \\
\hline Lactation & $\mathrm{b}^{1}$ & $\mathrm{c}^{2}$ & $\mathrm{~b}$ & $\mathrm{c}$ & $\mathrm{b}$ & $\mathrm{c}$ \\
\hline 1 & 0.1332 & -0.0029 & -0.2528 & 0.0028 & -0.1543 & 0.0023 \\
2 & 0.1171 & -0.0027 & -0.2207 & 0.0021 & -0.1676 & 0.0022 \\
$3+$ & 0.1020 & -0.0026 & -0.2172 & 0.0020 & -0.1624 & 0.0020 \\
\hline
\end{tabular}

${ }^{1} \mathrm{~b}=$ rate of increase until lactation peak; ${ }^{2} \mathrm{c}=$ rate of decline after the lactation peak

perts of the breeding organizations. The linear planning algorithm of Press et al. (1986) was used to select a least-cost ration based on the available feedstuffs (Table 5 ) that meets each day's protein and energy requirements (Table 6). The maximum loss of live mass due to energy deficit was assumed to be $8 \%$ at a maximum rate of $7.77 \mathrm{~g}$ per $\mathrm{kg}$ metabolic live mass $\left(\mathrm{LM}^{0.75}\right)$. In case of additional energy deficit, the milk production was reduced accordingly. A linear weight gain at the same maximum rate was modelled until the next kidding as soon as the energy balance for maintenance, production and gestation was positive. A maximum of $40 \%$ concentrate and $50 \%$ silage, respectively, and a minimum of $16 \%$ fiber content were assumed for the ration.

\subsection{Traits}

Following discussions with breeding organizations, economic values were derived for dairy, functional and fattening traits. Dairy traits included milk, fat and protein yield. For milk yield, the daily yield was increased by the same amount throughout lactation, while reducing fat and protein content to keep fat and protein yield constant. For fat and protein yield, contents were increased at constant milk yields.

With regard to the functional traits, fertility (represented by conception rate), stillbirth rate, rearing losses and longevity (represented by length of productive life) were considered. For all traits but longevity, improvements were made as onepercentage point incremental steps. To derive the economic values for longevity, the probability of involuntary culling was altered by one-percentage point steps in all lactations. This resulted in changes of herd structure and thus in a different profit. For fattening traits, only daily gain to reach the usual live weight of $20 \mathrm{~kg}$ and thus a slaughter weight of approximately $10 \mathrm{~kg}$ (e.g., Ringdorfer et al., 2002) was considered. For deriving economic values for daily gain, the parameters of the Gompertz curve (Fitzhugh, 1976) were changed in order to shorten the fattening period. As neither dressing percentage nor grading scores are relevant in kids, the average values for these traits (Table 2, Table 4) were assumed for the reference and all alternative scenarios.

Table 4. Assumed costs and prices (in €)

Tabelle 4. Angenommene Kosten und Preise (in €)

\begin{tabular}{|c|c|}
\hline Trait (unit) & $€ /$ unit \\
\hline Labor costs (h) & 14.00 \\
\hline Difficult kidding (case) & 50.00 \\
\hline First insemination ${ }^{1}$ (case) & 8.94 \\
\hline Slaughtered maiden goat (kg live mass) & 0.80 \\
\hline Replacement maiden goat (animal, 180 days old) & 240 \\
\hline Breeding buck (animal, 180 days old) & 500 \\
\hline Milk carrier/fat/protein $(\mathrm{kg})$ & $0.27 / 7.00 / 8.50$ \\
\hline$\varnothing$ slaughter weight $(\mathrm{kg})^{2}$ & 3.425 \\
\hline
\end{tabular}

${ }^{1}$ Costs for natural service rams (difference between purchase and retail price of rams, costs per barn unit, labor, veterinary costs and feed) were assumed. To enable the calculation per insemination, costs were split to a theoretical number of 40 goats in the herd according to Fuerst-Waltl and Baumung (2009).

$285 \%$ of kids in class 1 with $€ 3.50 / \mathrm{kg}, 15 \%$ in class 2 with $€ 3.00 / \mathrm{kg}$. 
Table 5. Costs per kilogram of dry matter (DM) (€/kg DM) and protein (g XP), energy (MJ ME), and fiber content (\%) for available feedstuffs Tabelle 5. Kosten pro kg Trockensubstanz (DM) (€/kg DM) und Protein (g XP), Energie (MJ ME) und Rohfaseranteil (\%) der unterstellten Futtermittel

\begin{tabular}{lcccc}
\hline & $€ / \mathrm{kg}$ DM & Protein $(\mathrm{g} \mathrm{XP})$ & ME $(\mathrm{MJ})$ & Fiber content $(\%)$ \\
\hline Hay, $2^{\text {nd }}$ cut & 0.20 & 133 & 9.05 & 28.4 \\
Grass silage, $1^{\text {st }}$ cut & 0.18 & 150 & 10.20 & 21.3 \\
Corn silage & 0.16 & 131 & 10.20 & 21.0 \\
Barley & 0.17 & 124 & 12.84 & 5.7 \\
Soybean & 0.50 & 398 & 15.88 & 6.2 \\
\hline
\end{tabular}

\section{Results and Discussion}

The marginal utilities, genetic standard deviations $\left(s_{\mathrm{a}}\right)$, and the economic values per genetic standard deviation are shown in Table 7 . For dairy traits, the genetic standard deviations were available from test-runs (data not shown), while for all the other traits, the genetic parameters were adopted from Fuerst-Waltl and Baumung (2009). Marginal utilities are related to an improvement in the trait mean by one unit and are expressed per average goat place and year. For the calculation of economic values, marginal utilities are multiplied with the genetic standard deviation of the respective trait.
Per kg milk yield, a marginal utility of 26.3 ct was estimated resulting in an economic value of $37.14 €$ per $s_{a}$. Corresponding values for fat and protein yields are marginal utilities of 7.35 and $9.42 € / \mathrm{kg}$ and economic values of 33.96 and $36.44 € / s_{a}$, respectively. Within the dairy traits, the relative weight (in \%) of milk yield : fat yield : protein yield $=35: 34: 32$ and is thus at an approximate ratio of $1: 1: 1$. For dairy sheep, the approximate ratio was $2: 1: 1.5$ (Fuerst-Waltl and Baumung, 2009). The reason for the much higher weight of carrier is that the price for milk yield was $0.10 \mathrm{ct} / \mathrm{kg}$ higher in sheep several years ago. Differences in prices for fat and protein yield are less markedly pronounced in dairy goats $(7.00$ and $8.50 € / \mathrm{kg})$

Table 6. Energy and protein requirements of goats $\left(\mathrm{LM}=\right.$ live mass $(\mathrm{kg}) ; \mathrm{LE}=$ Energy content of milk, $\mathrm{ME}_{\mathrm{t}}=$ Energy requirement for gravid uterus on day t of gestation; LMZ = gain in live mass (g/d)) (DLG, 1997; GfE, 2003; Kirchgessner, 2004)

Tabelle 6. Energie- und Proteinbedarf der Ziegen (LM = Lebendmasse $(\mathrm{kg})$, LE = Energiegehalt der Milch, $\mathrm{ME}_{\mathrm{t}}=$ Energiebedarf für Konzeptionsprodukte am Trächtigkeitstag t, LMZ = Lebendmassezunahme (g/d)) (DLG, 1997; GfE, 2003; Kirchgessner, 2004)

\begin{tabular}{|c|c|}
\hline \multicolumn{2}{|c|}{ Energy requirements (MJ ME) } \\
\hline Maintenance & $0.45 \mathrm{MJ} \mathrm{ME} / \mathrm{kg} \mathrm{LM} \mathrm{LM}^{0.75}$ \\
\hline Milk production & $\begin{array}{l}\mathrm{LE}(\mathrm{MJ} / \mathrm{kg})=0.38 \mathrm{Fat} \%+0.21 \text { Protein } \%+0.95 \\
\text { Efficiency factor }=0.63\end{array}$ \\
\hline Gestation & $\begin{array}{l}\mathrm{ME}_{\mathrm{t}}\left(\mathrm{MJ} / \mathrm{kg} \mathrm{LM}^{0.75}\right)=\left(-0,062-0,00342 \mathrm{t}+0,0000371 \mathrm{t}^{2}\right) \times \mathrm{LM}^{0.75} \mathrm{~kg} \\
\text { Efficiency factor }=0.30\end{array}$ \\
\hline \multirow[t]{3}{*}{ Growth } & $\begin{array}{l}\text { suckling kids: } \\
\mathrm{ME}=1.377+0.00714 \mathrm{LMZ}+0.00158(\mathrm{LM} \times \mathrm{LMZ})\end{array}$ \\
\hline & $\begin{array}{l}\text { ruminating, male: } \\
\mathrm{ME}=1.033+0.1553 \mathrm{LM}+0.01034 \mathrm{LMZ}+0.00085 \times(\mathrm{LM} \times \mathrm{LMZ})\end{array}$ \\
\hline & $\begin{array}{l}\text { ruminating, female: } \\
\mathrm{ME}=0.954+0.1602 \mathrm{LM}+0.00896 \mathrm{LMZ}+0.00104(\mathrm{LM} \times \mathrm{LMZ})\end{array}$ \\
\hline \multicolumn{2}{|c|}{ Protein requirements ( $\mathrm{XP})$} \\
\hline Maintenance & $\mathrm{g} \mathrm{XP} / \mathrm{d}=3.0 \mathrm{~kg} \mathrm{LM}{ }^{0.75}+15$ \\
\hline Milk production & $\mathrm{g} \mathrm{XP}=\mathrm{g}$ protein content per $\mathrm{kg}$ milk $/ 0.42$ \\
\hline Gestation & $\mathrm{g} \mathrm{XP} / \mathrm{d}=(10.5 / 0.83) \cdot \mathrm{ME}$ total requirements for maintenance and gestation ${ }^{1}$ \\
\hline Growth & $\mathrm{g} \mathrm{XP} / \mathrm{d}=2.670+0.7682 \mathrm{LM}+0.2269 \mathrm{LMZ}$ \\
\hline
\end{tabular}

${ }^{1} 10.5$ = average factor for microbial protein synthesis; 0.83 average protein degradation rate 
Table 7. Overview of all the traits considered, their heritabilities $\left(h^{2}\right)$ and genetic standard deviations $\left(s_{\mathrm{a}}\right)$, marginal utilities and economic values for the Saanen goats

Tabelle 7. Übersicht aller verwendeten Merkmale, ihrer Heritabilitäten $\left(h^{2}\right)$ und genetischen Standardabweichungen $\left(s_{\mathrm{a}}\right)$, Grenznutzen und ihrer wirtschaftlichen Gewichte bei der Saanenziege

\begin{tabular}{|c|c|c|c|c|c|}
\hline Trait & Unit & $\mathrm{h}^{2}$ & $s_{a}$ & Marginal utility (€/unit) & Economic value $(€ / \mathrm{sa})$ \\
\hline Milk carrier & $\mathrm{kg}$ & 0.59 & 141.2 & 0.26 & 37.14 \\
\hline Fat yield & $\mathrm{kg}$ & 0.50 & 4.62 & 7.35 & 33.96 \\
\hline Protein yield & $\mathrm{kg}$ & 0.54 & 3.87 & 9.42 & 36.44 \\
\hline Stillbirth & $\%$ & 0.02 & 3.1 & 0.49 & 1.52 \\
\hline Rearing losses & $\%$ & 0.05 & 6.1 & 0.82 & 5.00 \\
\hline Length of productive life & d & 0.12 & 189 & 0.055 & 10.39 \\
\hline Conception rate & $\%$ & 0.04 & 4.5 & 4.03 & 18.14 \\
\hline Daily gain & $\mathrm{g}$ & 0.30 & 29 & 0.060 & 1.75 \\
\hline
\end{tabular}

than they were in dairy sheep (4.43 and $7.41 € / \mathrm{kg}$; FuerstWaltl and Baumung, 2009). With milk yield : fat yield : protein yield $=27 \%: 39 \%: 34 \%$ in the German Federal country of Baden-Wurttemberg (Herold and Hamann, 2013), the relative weights within the dairy complex of goats is close to our results. In Switzerland, a genetic evaluation for dairy goats exists; however, so far, no total merit or sub- indices are calculated (www.szzv.ch) and thus no economic values are available.

Within the functional traits, the highest economic value was found for the fertility trait conception rate, followed by longevity, rearing losses and stillbirth with approximate relative weights (\%) of $52: 30: 14: 4$. In total, the economic value for fitness traits is much lower than that for dairy traits. This result is in accordance to the earlier results for Austrian dairy sheep (Fuerst-Waltl and Baumung, 2009). The economic value for longevity is however strikingly different - while for sheep, a slightly negative marginal utility and thus economic value was calculated, the economic value for longevity was the second highest of the functional traits considered. A possible reason therefore is that the milk yield of sheep decreases more strongly in higher age classes than that of goats.

The low economic values for stillbirth $\left(1.52 € / s_{\mathrm{a}}\right)$ and daily gain of fattening kids $\left(1.75 € / s_{\mathrm{a}}\right)$ reflect the difficult market situation of kids well. Higher economic values were observed for dairy sheep (Fuerst-Waltl and Baumung, 2009). We are not aware of comparable economic values for other goat populations. This may be due to the fact that the salability of lamb meat is much higher than that of goat meat in the developed western countries.

The relative economic values (in \%) for the trait complexes were as follows: dairy : functional traits : meat $=74: 25: 1$, respectively. Literature and information on economic values and on total merit indices for dairy goats is scarce. In France, sub-indices for dairy traits and morphology are routinely published for Alpine and Saanen goats. Within the dairy complex, milk yield : protein content : fat yield : fat content are weighted with a ratio of $1: 0.4: 0.2: 0.1$ for both breeds. Within the sub-index morphology, considering udder conformation traits, the four traits udder profile, udder height, shape of the rear udder and quality of the rear udder are weighted $1: 1: 1: 1$ and $1: 1: 0.5: 1$ in the Saanen and Alpine goats, respectively. In the calculated TMI, dairy traits and morphology are weighted (in \%) with $56: 44$ (Saanen goat) and $67: 33$ (Alpine goat) (Manfredi und Ådnøy, 2012). The weights are however not based on derived economic values. In 2013, the French TMI should have been extended by the functional trait Somatic Cell Count (Carillier et al., 2013), which however did not happen so far (http://en.france-genetique-elevage.org/Dairy-goats-breedsselection.html). As mentioned earlier, breeding values are published in Baden-Württemberg and Switzerland, but to our knowledge, neither economic values nor TMIs including functional traits are currently calculated.

\section{Conclusion}

For the first time, economic values were derived for dairy goats in Austria. These may be used to establish the basis for weighting different traits and trait complexes in a TMI and in sub-indices. Milk, fat and protein yield were found to have the highest economic importance; the relative weights of the trait complexes dairy : fitness : meat (in \%) were $74: 25: 1$. Such a high relative weight of dairy traits 
may however not be a sustainable approach, when actually introducing a TMI. Dairy traits have markedly higher heritabilities than functional traits, thus the relative genetic gain will be higher than the actual weight. For the lowheritability functional traits, no or even a negative development may be expected, when the weights are only based on economic values (e.g., Fuerst-Waltl et al., 2016). Thus, special emphasis needs to be placed on the long-term development of fitness-related traits. Further traits that may be additionally considered are persistency, udder health, milking speed and selected conformation traits. Due to the lack of data and/or lack of interest by the respective organizations when deriving the economic values, these were not included in this study. However, as economic values have to be re-calculated in regular intervals, those traits could be taken into account in future analyses. Following Fuerst-Waltl et al. (2016), next steps include calculations of expected selection responses considering the genetic and phenotypic (co)variance-matrices and the weighting factors from the calculation of the TMI as a basis for further discussions.

\section{Acknowledgements}

We wish to thank Dr. Leonhard Gruber (HBLFA Raumberg-Gumpenstein, Austria) for providing information regarding energy and protein requirements. We are grateful to the representatives of the breeding organizations for providing data and background information. Funding by the Austrian Federal Ministry of Sustainability and Tourism and the Austrian Sheep and Goat Association (Project $100884)$ is gratefully acknowledged.

\section{References}

Amer, P.R., Kaufmann, A. and N. Künzi (1996): Breed choice and pricing system implications for farmers and political institutions from a Swiss cattle farm model. In: Dent, J.B., McGregor, M.J. and A.R. Sibbald (Eds.): Livestock Farming Systems. Research, Development, Socio-Economics and the Land Manager. EAAP Publ. No. 79, Wageningen Academic Publishers, Wageningen, The Netherlands, pp. 253-258.

Carillier, C., Larroque, H., Palhière, I., Clément, V., Rupp, R. and C. Robert-Granié (2013): A first step toward genomic selection in the multi-breed French dairy goat population. Journal of Dairy Science 96, 7294-7305.

Dempfle, L. (1992): Berücksichtigung von Fruchtbarkeit und Eutergesundheit in der Rinderzüchtung. Züchtungskunde 64, 447-457.

DLG (1997): DLG-Futterwerttabellen Wiederkäuer. Deutsche Landwirtschaftsgesellschaft, 7. Aufl., DLGVerlag, Frankfurt/Main, Deutschland.

Fitzhugh, H.A. (1976): Analysis of growth curves and strategies for altering their shape. Journal of Animal Science 42, 1036-1051.

Fuerst-Waltl, B. and R. Baumung (2009): Economic values for performance and functional traits in dairy sheep. Italian Journal of Animal Science 8, 341-357.

Fuerst-Waltl, B., Fuerst, C., Obritzhauser, W. and C. Egger-Danner (2016): Sustainable breeding objectives and possible selection response: Finding the balance between economics and breeders' preferences. Journal of Dairy Science 99, 9796-9809.

GfE (2003): Empfehlungen zur Energie- und Nährstoffversorgung der Ziegen. Gesellschaft für Ernährungsphysiologie - Ausschuss für Bedarfsnormen, DLG-Verlag, Frankfurt/Main, Deutschland.

Groen, A.F., Steine, T., Colleau, J.J., Pedersen, J., Pribyl, J. and N. Reinsch (1997): Economic values in dairy cattle breeding, with special reference to functional traits. Report of an EAAP-working group. Livestock Production Science 49, 1-21.

Hazel, L.N. (1943): The genetic basis for constructing selection indexes. Genetics 28, 476-490.

Hazel, L.N. and J.L. Lush (1942): The efficiency of three methods of selection. Journal of Heredity 33, 393-399.

Herold, P. and H. Hamann (2013): Gemeinsam für die Milchziegenzucht. Herdenmanagement mit dem Ziegendatenverbund und Aufbau einer Zuchtwertschätzung. Internationale Bio-Schaf- und Bioziegentagung 2013, Puchberg/Wels, Österreich.

Kirchgessner, M. (2004): Tierernährung. 11. Aufl., DLGVerlag, Frankfurt/Main, Deutschland.

Manfredi, E. and T. Ådnøy (2012): Génétique des caprins laitiers. INRA Productions Animales 25, 233-244.

Miesenberger, J. (1997): Zuchtzieldefinition und Indexselektion für die österreichische Rinderzucht. Dissertation, Universität für Bodenkultur Wien (BOKU), Österreich.

ÖBSZ (2017): Jahresbericht 2016. Österreichischer Bundesverband für Schafe und Ziegen. http://www. 
alpinetgheep.com/jahresberichte.html. Accessed on 15 February 2018.

Press, W.H., Flannery, B.P., Teukolsky, S.A. and W.T. Vetterling (1986): Numerical Recipies: The Art of Scientific Computing. Cambridge University Press, Cambridge, UK.

Regadas Filho, J.G.L., Tedeschi, L.O., Rodrigues, M.T., Brito, L.F. and T.S. Oliveira (2013): Comparison of growth curves of two genotypes of dairy goats using nonlinear mixed models. Journal of Agricultural Science 152, 829-842.

Ringdorfer, F., Leitgeb, R. and R. Tscheliesnig (2002): Einfluss von Genotyp, Geschlecht und Lebendmasse auf die Mast- und Schlachtleistung sowie die Fleischqualität von Ziegenkitzen. Die Bodenkultur 53, 53-62.

Smith, C., James, J.W. and E.W. Brascamp (1986): On the derivation of economic weights in livestock improvement. Animal Production 43, 545-551.

Statistik Austria (2017): Milchstatistik 2016. http://www. statistik.at/wcm/idc/idcplg?IdcService=GET_PDF_FIL E\&RevisionSelectionMethod=LatestReleased\&dDocN ame=112840 Accessed February 15, 2018.

Wood, P.D.P. (1967): Algebraic model of the lactation curve in cattle. Nature 216, 164-165. 